\title{
Hyperbaric Oxygen Treatment
}

\section{Hiperbarik Oksijen Tedavisi}

\author{
Serkan ERGÖZEN ${ }^{1}$, Egemen KAYA ${ }^{2}$ \\ ${ }^{1}$ Muğla Sitkı Koçman University School of Medicine, Underwater and Hyperbaric Medicine Department, Muğla \\ ${ }^{2}$ Muğla Sitk1 Koçman University School of Medicine, Physiology Department, Muğla
}

\begin{abstract}
Hyperbaric oxygen has been used to treat several diseases such as decompression sickness, chronic non-healing wounds and carbon monoxide poisoning for many years. Several physicians hear or read some information about it, but without details. This review aims to be shared the basic knowledge about the definition, technical aspects, history, mechanism of actions, indications, contraindications and complications of hyperbaric oxygen treatment.
\end{abstract}

Keywords: Barotrauma, Hyperbaric Oxygen Treatment, Hyperoxia, Oxygen Toxicity, Wound Healing

\section{Introduction}

Hyperbaric oxygen treatment (HBOT) is a treatment modality which is applied in a specially constructed pressure chamber and patient breathes oxygen $\left(\mathrm{O}_{2}\right)$ via tight fitting mask, hood, endotracheal tube or in mono-place chambers from the chamber environment at higher pressures than 1 ATA (atmosphere absolute). On the basis of HBOT, $\mathrm{O} 2$ supply and the arterial $\mathrm{O} 2$ pressure are increased. Local application of $\mathrm{O}_{2}$ and breathing $\mathrm{O}_{2}$ at 1 ATA are not accepted as HBOT (1). HBOT chambers can be classified basically as mono-place or multi-place chambers. In mono-place chambers, only one patient can be treated whereas more patients can be treated in multi-place chambers at the same time. These chambers are generally built of steel and acrylic material. If desired, mono-place chambers can be pressurized with $\mathrm{O}_{2}$, but multi-place chambers cannot be done, in terms of safety. Except some special conditions such as decompression sickness and arterial gas embolism, generally the duration of a routine HBOT session is between 60-120 minutes and the treatment pressure is 1.3-2.8 ATA. If some emergency conditions exist, HBOT can be given even more than 1 session in a day. $\mathrm{O}_{2}$ is not administered at pressures higher than 3 ATA due to its toxic effects.

\begin{tabular}{|c|c|}
\hline \multirow{3}{*}{$\begin{array}{l}\text { Serkan ERGÖZEN } \\
\text { Egemen KAYA }\end{array}$} & \multirow{2}{*}{$\begin{array}{l}\text { ORCID No } \\
0000-0003-1171-3703\end{array}$} \\
\hline & \\
\hline & $0000-0003-0466-7294$ \\
\hline Başvuru Tarihi / Received: & 31.10 .2018 \\
\hline Kabul Tarihi / Accepted : & 06.11 .2018 \\
\hline Adres / Correspondence & Serkan ERGÖZEN \\
\hline \multicolumn{2}{|c|}{$\begin{array}{l}\text { Muğla Sitkı Koçman University School of Medicine, Underwater } \\
\text { and Hyperbaric Medicine Department, Muğla }\end{array}$} \\
\hline e-posta / e-mail & serkanergozen@mu.edu.tr \\
\hline
\end{tabular}

\section{Öz}

Hiperbarik oksijen uzun yıllardır dekompresyon hastalığı, kronik iyileşmeyen yaralar ve karbonmonoksit zehirlenmesi gibi birçok hastalığın tedavisinde kullanılmaktadır. Bircok doktor detaylı olmamakla birlikte tedavi hakkında bazı bilgiler duymakta veya okumaktadır. Bu derleme, hiperbarik oksijen tedavisinin tanımı, teknik özellikleri, etki mekanizmaları, endikasyonları, kontrendikasyonları ve komplikasyonları hakkındaki temel bilgilerin paylaşılmasını amaçlamaktadır.

Anahtar Kelimeler: Barotravma, Hiperbarik Oksijen Tedavisi, Hiperoksi, Oksijen Toksisitesi, Yara Iyileşmesi

\section{History}

The first documented history of hyperbaric treatments began with the British physician Henshaw in 1662. But it was not possible to talk about hyperbaric "oxygen" treatment at that time as $\mathrm{O}_{2}$ had not been isolated yet. Henshaw built his chamber, named domicilium, and tried to treat patients with compressed air. After the isolation of $\mathrm{O}_{2}$ by another British scientist Joseph Priestly in 1775, medical community met $\mathrm{O}_{2}$ treatments. However, its use in under pressure had not been recommended until the 1930s due to its toxic effects. Behnke and Shaw were the first who started using $\mathrm{O}_{2}$ under pressure to treat decompression sickness in 1937 and they opened the doors for HBOT (2-4). Cardiovascular surgeon Ite Boerema is the scientist who first started the scientific based treatment approaches at the end of 1950s and HBOT applications have rapidly been developing so far (5). In Turkey, following that Dr. Maide Çimşit had been assumed as "specialist" in Underwater Medicine in England, Underwater Medicine Departments were first based in İstanbul University and Gülhane Military Medical Academy Haydarpaşa Training Hospital in 1984. The name of the department Underwater Medicine was altered and took its final version as Underwater and Hyperbaric Medicine in $2002(4,6,7)$.

\section{Mechanisms of Action}

HBOT shows its physiological and pharmacological effects basically with two main mechanisms. The first of these is the mechanical effect of high pressure and the other one is the elevated partial pressure of oxygen $\left(\mathrm{pO}_{2}\right)$ while breathing $100 \% \mathrm{O}_{2}$ inside the compressed chamber: 


\section{Mechanical Effect of High Pressure:}

According to Boyle's Law, when temperature is kept constant, the volume of a gas in a container is conversely proportional to its pressure (5). This means that when the pressure is elevated over a confined gas, its volume decreases and vice versa $(2,8)$. In clinical practice, the mechanical effect of HBOT is used to decrease the volume of pathologically formed gas bubbles in tissues as it happens in decompression sickness and arterial gas embolism in order to attenuate the harm due to these bubbles $(2,9,10)$. All anatomical and pathological gas spaces in the body are affected from pressure changes and this pressure-volume changes are the basis of some complications which are classified as barotrauma (8).

\section{Effects of Elevated Partial Pressure of Oxygen:}

Henry's Law states that, the amount of gas dissolved in a liquid is directly proportional to its pressure when temperature is kept constant and the gas does not react with the solvent (5). That means that the more amount of the gas dissolves in the liquid when the pressure of a gas in contact with the liquid is elevated. The $\mathrm{O}_{2}$ content and $\mathrm{pO}_{2}$ levels of patient's blood and interstitial fluid are elevated during hyperbaric oxygenation according to this law and anti-hypoxic effect of HBOT occurs $(2,4)$. Antihypoxic and hyperoxic effects of HBOT mediate its anti-toxic, anti-edema, anti-infectious and wound healing effects. Hyperoxic effect of HBOT is also related to some complications due to high $\mathrm{pO}_{2}$ levels. Under the normal conditions, air is composed of $21 \% \mathrm{O}_{2}$ and it results in $100 \mathrm{mmHg}$ alveolar $\mathrm{O}_{2}$ pressure. With the very little amount of dissolved plasma $\mathrm{O}_{2}$, plasma hemoglobin is saturated and $1 \mathrm{~g}$ of hemoglobin $(\mathrm{Hb})$ carries approximately $1.34 \mathrm{~mL}$ of $\mathrm{O}_{2}$. When blood average $\mathrm{Hb}$ content is assumed $15 \mathrm{~g} / \mathrm{dL}$ and saturated $97 \%$ with $\mathrm{O}_{2}, 100 \mathrm{~mL}$ of blood has approximately $19.4 \mathrm{~mL}$ of $\mathrm{O}_{2}$. The amount of $\mathrm{O}_{2}$ dissolved in $100 \mathrm{~mL}$ of plasma is only $0.32 \mathrm{~mL}$. Under normal conditions again, $5 \mathrm{~mL}$ of $\mathrm{O}_{2}$ for each $100 \mathrm{~mL}$ of blood is carried to the tissues to be utilized (11). The main changes in blood during HBOT happen not on the $\mathrm{Hb}$ of which $97 \%$ saturated normally, but on the amount of $\mathrm{O}_{2}$ dissolved in the plasma. The dissolved amount of $\mathrm{O}_{2}$ in $100 \mathrm{~mL}$ of plasma during HBOT is $4.44 \mathrm{~mL}$ at 2 ATA, $5.62 \mathrm{~mL}$ at 2.5 ATA and $6.8 \mathrm{~mL}$ at 3 ATA $(3,10)$. At 3 ATA the combined arterial blood $\mathrm{O}_{2}$ content is 26.9 $\mathrm{mL} / \mathrm{dL}$, increasing from $20.4 \mathrm{~mL} / \mathrm{dL}$ which is under normal conditions. When all these calculations are considered, the application of HBOT under the pressures which are equal or greater than 2.5 ATA can supply the basal $\mathrm{O}_{2}$ need for survival only with hyperoxygenated plasma without erythrocytes (10). Ite Boerema revealed this theoretical information by his experimental study on swine $(2,4)$. In the body, most of the $\mathrm{O}_{2}$ is used for the cellular respiration, in which the adenosine triphosphate is formed. HBOT presents enough plasma $\mathrm{O}_{2}$ to maintain cellular respiration and to succeed in dealing with hemorrhage. Although it is not in the indication list in Turkey, this hyperoxygenation effect of HBOT on plasma is used in some countries to treat patients with severe anemia who refuse blood transfusion due to their religious beliefs.

HBOT can restore microcirculation by improving the deformability of erythrocytes $(4,12)$. However, ischemic and hypoxic areas, which erythrocytes cannot reach physically despite improved deformability, can be oxygenated via high $\mathrm{O}_{2}$ levels dissolved in the plasma (12).

HBOT can increase $\mathrm{pO}_{2}$ levels to higher than $2000 \mathrm{mmHg}$ in arterioles, $500 \mathrm{mmHg}$ in tissues $(8,12,13)$. These high $\mathrm{pO}_{2}$ levels in arterioles increase the $\mathrm{O}_{2}$ gradient, which is the driving force for $\mathrm{O}_{2}$ diffusion to the tissues, and can improve diffusion distance of $\mathrm{O}_{2}$ to 3-4 fold of the normal diffusion distance.

$\mathrm{O}_{2}$ causes vasoconstriction by decreasing the nitric oxide production which is secreted from the endothelial cells. HBOT makes vasoconstriction without causing hypoxia by its hyperoxygenation effect and decreases capillary pressure, thereby decreases vascular permeability and accelerates the return of edema to the intravascular site $(4,14)$. With these mechanisms, HBOT is very effective in correcting tissue ischemia and hypoxia caused by edema $(10,15)$

Carbon monoxide $(\mathrm{CO})$ poisoning is one of the conditions which HBOT is used. $\mathrm{CO}$ binds to hemoglobin 200-250 times more tightly than $\mathrm{O}_{2}$. It disrupts the cellular respiration and forms a deadly condition. HBOT reduces the half-life of $\mathrm{CO}$ dissociation and detaches the $\mathrm{CO}$ from hemoglobin and acts its anti-toxic effect $(2,4)$.

HBOT also shows its anti-toxic effects by inhibiting the $\alpha$ (alpha) toxin of Clostridia in gas gangrene $(10,15,16)$.

Normalization of tissue $\mathrm{pO}_{2}$ levels is very important for treating infections (17). HBOT has effects on anaerobic and aerobic bacteria. It has direct killing effect on anaerobes and bacteriostatic effect on aerobes over 1.3 ATA $(10,17)$. HBOT also has beneficial effects on leukocytes. Oxidative killing of bacteria by leukocytes following phagocytosis is directly related to local $\mathrm{pO}_{2}$ levels at the infection site $(18,19)$. Hypoxic conditions decrease the effectiveness of bacterial killing mechanisms of leukocytes (20). Some studies report that $\mathrm{pO}_{2}$ levels of $45-80 \mathrm{mmHg}$ are needed for the half-maximal and more than $300 \mathrm{mmHg}$ are needed for the maximal production of reactive $\mathrm{O}_{2}$ species as a result of oxidative burst in neutrophils and macrophages $(18,21)$. HBOT supplies the $\mathrm{O}_{2}$ which is needed by the leukocytes for oxidative burst by increasing the oxygenation in the infection site, 
thereby potentiates the anti-bacterial effects of leukocytes $(1,15)$.

Increased tissue oxygenation by HBOT decreases the minimum inhibitory concentration (MIC) and the minimum bactericidal concentration (MBC) of penicillins, aminoglycosides, sulfamethoxazole and trimethoprim, vancomycin, teikoplanin and fluoroquinolones $(5,10,17)$. According to the data, it is possible to indicate that HBOT applied with antibiotics simultaneously, in case of an infection, can be very beneficial to treat infection.

Wound healing is basically consisted of inflammatory, proliferative and remodelling phases $(20,22)$. The cells which are responsible for inflammatory and proliferative phases need $\mathrm{O}_{2}(13)$. Chronic wounds are generally stalled in the inflammatory phase due to the local tissue hypoxia and the infection (23). Hypoxia deepens from the periphery of the wound to the center of it. Some studies report the converse proportion between the $\mathrm{O}_{2}$ tension and the risk of infection development in subcutaneous tissues $(24,25)$. Collagen production process is $\mathrm{O}_{2}$ dependent and fibroblasts need 30-40 $\mathrm{mmHg}$ of $\mathrm{pO}_{2}$ for collagen deposition. Hydroxylation of proline and lysine which plays role in collagen synthesis and cross linking of collagens which is responsible for tensile strength of the wound are also $\mathrm{O}_{2}$ dependent $(13,18,20)$. If transcutaneous $\mathrm{O}_{2}$ tension measurement in a wound is higher than $50 \mathrm{mmHg}$, the wound can be expected to be healed spontaneously; but if it is lower than 30 $\mathrm{mmHg}$, it cannot heal without support (13). Another key factor for wound healing is the development of new blood vessels in the collagen matrix.

Wound healing is one of the most common use of HBOT. By HBOT, $\mathrm{O}_{2}$ carried by plasma is increased 10-20 times more than breathing at sea level, wound healing is promoted. HBOT has been shown to promote angiogenesis by changing the hypoxic environment of the wound to normoxic and even hyperoxic conditions $(1,9,10,16)$. HBOT also modulates and upregulates the growth factors like vascular endothelial growth factor, platelet-derived growth factor, and fibroblast growth factor. They induce capillary and neural development, cell proliferation, wound granulation. At the wound site, $\mathrm{O}_{2}$ is also needed for killing bacteria and removing necrotic material by neutrophils and macrophages. They use the $\mathrm{O}_{2}$ to form reactive oxygen species.

Considering all these factors above, treating or preventing tissue infections, decreasing tissue edema, cell proliferation, collagen synthesis, angiogenesis and epithelialization are needed for wound healing and all of these processes require sufficient $\mathrm{O}_{2}$ in the wound site. HBOT is a very useful adjunctive treatment modality to optimize wound environment for healing $(12,13)$.

\section{Indications}

Indications for HBOT change according to the national regulations of each country. In Turkey, the list of indications for HBOT approved by Turkish Ministry of Health and under the reimbursement policy of Turkish Social Security Institution, is formed from the indications and recommendations list of Undersea and Hyperbaric Medical Society (UHMS) and European Committee for Hyperbaric Medicine (ECHM) (26-28).

1. Decompression sickness

2. Arterial gas embolism

3. Carbon monoxide and cyanide poisoning, acute smoke inhalation

4. Gas gangrene

5. Necrotising soft tissue infections

6. Crush injury, compartment syndrome and other acute traumatic ischemic conditions

7. Non-healing wounds (diabetic or non-diabetic)

8. Chronic refractory osteomyelitis

9. Radiation necrosis

10. Compromised skin grafts and flaps

11. Thermal burns

12. Brain abscess

13. Anoxic encephalopathy

14. Sudden hearing loss

15. Retinal artery occlusion

16. Acute osteomyelitis of head bones, sternum and vertebra

17. Osteonecrosis

\section{Contraindications}

Untreated pneumothorax is accepted as the only absolute contraindication for HBOT $(29,30)$. If a patient with pneumothorax must be treated with HBOT, chest tube should be inserted before the treatment $(4,16,30)$. Furthermore, there are some relative contraindications which might increase the risk of the complications. Some of these are upper respiratory infections, uncontrolled high fever, previous chest or middle ear implant surgery, congenital spherocytosis, epilepsy, pregnancy, chronic obstructive pulmonary disease, air cysts or blebs of lungs, severe congestive heart failure, claustrophobia, optic neuritis, active cancer, some psychiatric disorders, some pacemakers and doxorubicin, cis-platinum, disulfiram and mafenide acetate use $(3,4,29,30)$.

\section{Complications}

\section{Barotrauma of the middle ear, paranasal sinus, tooth and lung:}

The most frequent complication of HBOT is the middle ear barotrauma $(3,4,8,31)$. This complication generally occurs in the compression phase of the treatment. When pressure increases in the chamber, 
gas volume in the middle ear space decreases according to Boyle' $\mathrm{s}$ Law and the tympanic membrane is sucked into the middle ear space. If the patient cannot equalize the middle ear pressure to the environmental pressure of the chamber by pressure equalizing manoeuvres, ear pain and hyperemia in the tympanic membrane occurs. And if the compression is not stopped at this moment, hyperemia progresses to bleeding and finally tympanic membrane might be perforated. Paranasal sinuses and gas pockets inside the dental caries, crowns and fillings are also affected in the same way. Consequently, patient may complain about pain on the sinus or tooth, mostly during the compression phase of the treatment and during the decompression phase, mild nose bleeding, dislocation of dental crown or dental filling may occur (31).

Asymptomatic bullae or blebs of lung can be ruptured during the decompression phase of the treatment, because of the expansion of air inside them, and can cause subcutaneous emphysema, pneumomediastinum, pneumothorax and arterial gas embolism. Fortunately, this complication is seen seldomly $(8,30)$. Patients with mechanical ventilator support are under the risk of pulmonary barotrauma during HBOT, so the inside attendant must be careful about this risk.

\section{Myopia and cataract:}

Myopia which develops during HBOT is generally reversible in a few weeks to months following the cessation of the treatment $(8,9,30)$. Development of cataract has been rarely reported in patients who had extremely high numbers of HBOT sessions, over 100-150 sessions that we do not apply in clinical practice nowadays $(8,9,32)$. But there is a case in the literature reporting that a 49-year old patient who had a de novo cataract after completing 48 sessions of HBOT (32). Contrary to hyperbaric/hyperoxic myopia, cataract is not reversible $(9,33)$.

\section{Oxygen toxicity of central nervous system (CNS):}

Also known as Paul Bert' s effect $(1,4,30)$. It is one of the rarely seen but most serious complications of HBOT. The incidence of $\mathrm{CNS} \mathrm{O}_{2}$ toxicity has been reported in different studies as 1-6/10.000 of HBOT sessions $(8,9)$. Although the exact mechanism is not known, free radicals may play role. Carbon dioxide retention, hypoglycaemia, hyperthyroidism, $\mathrm{CO}$ poisoning and inhalation of $\mathrm{O}_{2}$ for long duration under hyperbaric environment are reported as risk factors (4,8). Seizure ends spontaneously when $\mathrm{O}_{2}$ inhalation is discontinued. Residual effect due to $\mathrm{O}_{2}$ seizure is not observed $(8,33)$. Air breaks are given between $\mathrm{O}_{2}$ inhalation periods to decrease the risk of CNS toxicity.

\section{Pulmonary oxygen toxicity (POT):}

Also called "Lorrain-Smith effect". Development of POT is related both with $\mathrm{FiO}_{2}$ (Fraction of Inspired $\mathrm{O}_{2}$ ) and the duration of inhalation $(4,8,34)$. In fact, POT is not expected generally in daily routine HBOT sessions, because the time needed for a session is shorter than the time needed for POT development, but some extended treatment tables which have long durations of $\mathrm{O}_{2}$ inhalation are applied in special conditions such as decompression sickness and arterial gas embolism, so POT can be observed in these cases. Symptoms of POT begins with the feeling of mild substernal discomfort, especially while inhaling, and as $\mathrm{O}_{2}$ exposure continues, chest pain, cough and dyspnea can supervene. Symptoms regress rapidly following cessation of $\mathrm{O}_{2}$ inhalation $(4,8)$.

\section{Conclusions}

HBOT has been used to treat several diseases for many years. Its mechanisms of action have been investigated so far and these investigations will surely continue from now on. Firstly, knowing the correct definition of the treatment is significant. Besides, understanding the physical and the physiological mechanisms underlying leads us to comprehend its healing effects and complications. In the view of complications, HBOT can be accepted as a "safe" treatment modality. Considering its mechanisms of action, HBOT must be a part of interdisciplinary approach to the diseases and must not be accepted as the last option.

\section{References}

1. Vandana M, Abishek De CB. Hyperbaric oxygen therapy. J Pakistan Assoc Dermatologists. 2009;19:164-7.

2. Jones MW, Wyatt HA. Hyperbaric, Physics. StatPearls [Internet]. Treasure Island (FL): StatPearls Publishing. 2018.

3. Jain KK. Textbook of Hyperbaric Medicine, 5th edn. Göttingen: Hogrefe \& Huber Publishers, 2009.

4. Cimșit M. Hiperbarik Tıp, 1st edn. Ankara: Eflatun Yayınevi, 2009.

5. Mathieu D. Handbook on Hyperbaric Medicine. Dordrecht: Springer, 2006.

6. http://www.itf.istanbul.edu.tr/sualtihekimligi/TARİHÇE.ht $\mathrm{m}$

7. https://gulhanetip.sbu.edu.tr/Akademik/SualtiHekimligiVeH iperbarikTipAnabilimDal

8. Heyboer M, Sharma D, Santiago W, McCulloch N. Hyperbaric Oxygen Therapy: Side Effects Defined and Quantified. Adv Wound Care. 2017;6(6):210-24.

9. Thom SR. Hyperbaric oxygen -its mechanism and efficacy. Plast Reconstr Surg. 2011;127(Suppl 1):131-41.

10. Sahni T, Singh P, John MJ. Hyperbaric oxygen therapy: current trends and applications. J Assoc Physicians India. 2003;51:280-4.

11. Hall JE. Guyton and Hall Textbook of Medical Physiology, 13th eds. Philadelphia: Elsevier. 2016.

12. Gill AL, Bell CN. Hyperbaric oxygen: its uses, mechanisms of action and outcomes. QJM. 2004;97(7):385-95.

13. Zamboni WA, Browder LK, Martinez J. Hyperbaric oxygen and wound healing. Clin Plast Surg. 2003;30(1):67-75.

14. Dooley JW, Mehm WJ. Noninvasive assessment of the vasoconstrictive effects of hyperoxygenation. J Hyperb Med. 1990;4(4):177-87. 
15. Jones MW, Cooper JS. Hyperbaric, Wound Healing. StatPearls [Internet]. Treasure Island (FL): StatPearls Publishing; 2018.

16. Leach RM, Rees PJ, Wilmshurst P. ABC of oxygen: Hyperbaric oxygen therapy. BMJ. 1998;317:1140-3.

17. Park MK, Myers RA, Marzella R. Oxygen tensions and infections: modulation of microbial growth, activity of antimicrobial agents and immunologic responses Clin Infect Dis. 1992;14(3):720-40.

18. Tandara AA, Mustoe TA. Oxygen in wound healing - more than a nutrient. World J Surg. 2004;28(3):294-300.

19. Yip WL. Influence of oxygen on wound healing. Int Wound J. 2015;12(6):620-4

20. Rodriguez PG, Felix FN, Woodley DT, Shim EK. The role of oxygen in wound healing: a review of the literature. Dermatol Surg. 2008;34(9):1159-69.

21. Allen DB, Maguire JJ, Mahdavian M, et al. Wound hypoxia and acidosis limit neutrophil bacterial killing mechanisms. Arch Surg. 132(9):991-6.

22. Gonzalez AC, Costa TF, Andrade ZA, Medrado AR. Wound healing - A literature review. An Bras Dermatol. 2016;91(5):614-20

23. Thistlethwaite KR, Finlayson KJ, Cooper PD, et al. The effectiveness of hyperbaric oxygen therapy for healing chronic venous leg ulcers: a randomised, double blind, placebo-controlled trial. Wound Repair Regen. 2018;Epub ahead of print. doi: 10.1111/wrr.12657

24. Greif R, Akça O, Horn EP, Kurz A, Sessler DI. Supplemental perioperative oxygen to reduce the incidence of surgicalwound infection. N Engl J Med. 2000;342(3):161-7.
25. Hopf HW, Hunt TK, West JM, et al. Wound tissue oxygen tension predicts the risk of wound infection in surgical patients. Arch Surg. 1997;132(9):997-1004

26. https://www.uhms.org/resources/hbo-indications.html

27. Mathieu D, Marroni A, Kot J. Tenth european consensus conference on hyperbaric medicine: recommendations for accepted and non-accepted clinical indications and practice of hyperbaric oxygen treatment. Diving Hyperb Med. 2017;47(1):24-32.

28. http://www.sgk.gov.tr/wps/portal/sgk/tr/kurumsal/merkezteskilati/ana_hizmet_birimleri/gss_genel_mudurlugu/anasay fa_duyurular/degisiklik_tebligi_islenmis_guncel_sut_08022 018

29. Howell RS, Criscitelli T, Woods JS, Gillette BM, Gorenstein S. Hyperbaric Oxygen Therapy: Indications, Contraindications, and Use at a Tertiary Care Center. AORN J. 2018;107(4):442-53.

30. Foster H. Hyperbaric oxygen therapy : contraindications and complications. J Oral Maxillofac Surg. 1992;50(10):1081-6.

31. Heyboer M. Hyperbaric Oxygen Therapy Side Effects Where Do We Stand? J Am Coll Clin Wound Spec. 2016;8(1 3):2-3.

32. Gesell LB, Trott A. De Novo cataract development following a standard course of hyperbaric oxygen therapy. Undersea Hyperb Med. 2007;34(6):389-92

33. Neuman TS, Thom SR. Physiology and Medicine of Hyperbaric Oxygen Therapy 1st eds. Philadelphia: Saunders. 2008.

34. Clark JM, Lambertsen CJ, Gelfand R, et al. Effects of prolonged oxygen exposure at 1.5, 2.0, or 2.5 ATA on pulmonary function in men (predictive studies V). J Appl Physiol (1985). 1999;86(1):243-59. 